\title{
COMMENT
}

\section{The new prescriptivism?}

It's in the air, but only just. It isn't the same as the old prescriptivism, against which liberals in linguistics and general education have railed since the $1960 \mathrm{~s}$, but it necessarily shares a great deal with it. Nor is it a mark of - or a concession to-defenders of the old order, such as the Queen's English Society, although its members may take heart at finding such a tender seedling on their doorstep.

It appears to run parallel to the 'Third Way' that so prominently figures in the ideology (if that is the right word) of such leaders as Bill Clinton and Tony Blair - a difficult-to-pin-down approach that is not left or right or even centre. This cautious development is a response to issues that have slowly emerged worldwide in debates on language education in the $80 \mathrm{~s}$ and $90 \mathrm{~s}$, a response that focuses on what young people on leaving school can - and should - be able to do with language. It appears to be becoming all right once more to think and talk in terms of 'aims' and 'values' and even 'standards' in the use of Standard English. And this cautious toe-in-the-water 'new prescriptivism' is gently present throughout ET59:

- It can be detected in the background of Keith Davidson's article on the teaching of reading and writing, and comes to the fore at the close of article, when he comments (and it is a resounding compliment too): 'In the absence of a global authority, English Today is the international forum where the issues can be aired.'

- It has echoes in David Crystal's consideration of how language and literature can - should? - be studied together, a matter that ultimately affects syllabuses.

- Its characteristically gentle firmness (insisting that we look at how language is used in order to raise people's awareness about using language) emerges in the contributions of both Maria Estling and Pam Peters.

- And it is carefully clear-cut in Samuel Ahulu's assessment of what we may - should? must? - accept when teaching international standard English and making a 'reasonable accommodation' to both the facts and our students' needs.

In addition, although Donald Hook on the apostrophe, Tim Connell on geopolitical names, and Gloria George on lexicography and sexual orientation have very different aims and perspectives, all of them are saying: "Take note - there is much to be done, and done properly.'

Tom McArthur

The editorial policy of English Today is to provide a focus or forum for all sorts of news and opinion from around the world. The points of view of individual writers are as a consequence their own, and do not reflect the opinion of the editorial board. In addition, wherever feasible, ET generally leaves unchanged the orthography (normally British or American) and the usage of individual contributors, although the editorial style of the journal itself is that of Cambridge University Press. 